\title{
Effects of different concentrations of sodium ions on the self-assembly of amphotericin $B$ and DPPC at the air-water interface
}

\author{
Juan Wang', Tuo $\mathrm{Li}^{1}$, Yahong Ma,3, Zongcheng Miao \\ ${ }^{1}$ Shaanxi Engineering Research Center of Controllable Neutron Source, \\ Xijing University, Xi'an, 710123, China \\ 2 School of Electronic Information Engineering Internet of Things and Big \\ Data Research center, Xijing University, Xi'an, 710123, China \\ 3 The Fourth Military Medical University, Xi'an, 710032,China \\ ${ }^{4}$ Department of Science, Xijing University, Xi'an, 710123, China
}

Received March 28, 2018

\begin{abstract}
Amphotericin B is a widely used polyene antifungal drug for the treatment of deep fungal infections. This drug could cause pores on the cell membrane. In this work, we used the dipalmitoylphosphatidylcholine monolayer as the model of cell membrane in half. The influence of $\mathrm{Na}^{+}$ions on the interaction between amphotericin $\mathrm{B}$ and biomembrane were studied by analysis of phase transition and thermodynamic properties of monolayers. The $\mathrm{Na}^{+}$ions may affect the molecular orientation of amphotericin B, and it depends on the concentration of sodium ions. Low concentration of $\mathrm{Na}^{+}$ions has an opposite effect to high concentration of that. The results are helpful for obtaining some information on the influence mechanism in the level of sodium ions on the interaction between amphotericin $\mathrm{B}$ and biomembrane in the angle of physics.
\end{abstract}

Keywords: $\mathrm{Na}^{+}$ions, amphotericin $\mathrm{B}$, phase transition, intermolecular interaction

\begin{abstract}
Амфотерицин В является широко используемым полиеновым противогрибковым препаратом для лечения глубоких грибковых инфекций. Этот препарат может вызвать поры на клеточной мембране. Использовали двухслойный дипальмитоилфосфатидилхолин в качестве модели клеточной мембраны. Влияние ионов $\mathrm{Na}^{+}$на взаимодействие между амфотерицином В и биомембраной изучалось путем анализа фазового перехода и термодинамических свойств монослоев. Ионы $\mathrm{Na}^{+}$могут влиять на молекулярную ориентацию амфотерицина В в зависимости от их концентрации. Низкая концентрация ионов $\mathrm{Na}^{+}$оказывает противоположное влияние чем их высокая концентрация. Результаты полезны для получения информации о механизме влияния ионов натрия разной концентрации на взаимодействие между амфотерицином В и биомембраной с точки зрения физики.
\end{abstract}

Вплив різних концентрацій іонів натрію на самоосадження амфотерицину В i DPPC на кордоні розділу повітря-вода. Juan Wang, Tuo Li, Yahong Ma, Zongcheng Miao

Амфотерицин В $є$ широко використовуваним поліеновим протигрибковим препаратом для лікування глибоких грибкових інфекцій. Цей препарат може викликати пори на клітинній мембрані. у роботі використовували двошаровий діпальмітоілфосфатиділхолін (DPPC) в якості моделі клітинної мембрани. Вплив іонів $\mathrm{Na}^{+}$на взаємодію між амфотерицином В і біомембраною вивчено шляхом аналізу фазового переходу i термодинамічних властивостей монощарів. Іони $\mathrm{Na}^{+}$можуть впливати на молекулярну орієнтацію амфотерицину В в залежності від їх концентрації. Низька концентрація іонів $\mathrm{Na}^{+}$надає протилежний вплив ніж їх висока концентрація. Результати корисні для отримання інформації про механізм впливу іонів натрію різної концентрації на взаємодію між амфотерицином В і біомембраною з точки зору фізики. 


\section{Introduction}

Amphotericin B (AmB) is a widely used polyene antifungal drug for the treatment of deep fungal infections [1]. Its pharmacodynamic mechanism is that amphotericin B can make pores formed on the membrane of fungi, which causes to the dead of the fungus [2]. However, when amphotericin B exerts antifungal effects, it also could influence the property of the host cell membrane $[3,4]$ and destroy the structure of the cell membrane, which affect the transmembrane transport of normal living ions. So, this drug has very serious toxic and side effects. It is particularly easy to cause nephrotoxicity in patients with proteinuria, azotemia, hypokalemia, anemia and other symptoms, which greatly limits its clinical application. Therefore, the study of antifungal molecular mechanism of amphotericin B and its mechanism of cell membrane toxicity has become an important scientific problem.

Many scholars have found that this membrane pores by amphotericin B formed on the membrane affects transmembrane transport of metal cations, especially of potassium [5]. At the same time, there is an interplay between metal cations and amphotericin B on the membrane. Gagos et al. [6] found that potassium and sodium ions can induce changes in the localization of amphotericin B molecules on the membrane. L.Becucci [7] found that calcium ions could significantly promote the aggregation of amphotericin B. In addition, R. Turcu et al. [8] found that the intake of high sodium salts can, to some extent, reduce the effect of amphotericin B on mammalian cell membrane permeability. It can be seen that potassium, sodium and calcium ions may have special effects on the aggregation of amphotericin B on the membrane. However, Most scholars have pay more attention to the effects of potassium and calcium ions on amphotericin B. The studies about the effects of sodium ions are limited. The special role of sodium ions on the interaction between this drug and biomembrane can not be ignored and is worth in-depth study.

In this work, we used the dipalmitoylphosphatidylcholine (DPPC) monolayer as the model of cell membrane in half. The influence of $\mathrm{Na}^{+}$ions on the interaction between amphotericin B and biomembrane were studied by analysis of phase transition and thermodynamic properties of monolayers. The results are helpful for obtaining some information on the influence mechanism in the molecular level of sodium ions on the interaction between amphotericin B and biomembrane in the angle of physics.

\section{Experimental}

\subsection{Materials}

Dipalmitoylphosphatidylcholine (DPPC: purity $\geq 99 \%$ ), power amphotericin B (purity $>75 \%$ ) and Tris (hydroxymethyl) aminomethane (Tris: purity $\geq 99.9 \%$ ) were purchased from Sigma, USA. The other chemicals were of analytical grade and were used without further purification. DPPC were dissolved in a chloroform/methanol mixture $(9: 1, \mathrm{v} / \mathrm{v})$ to give a final concentration of $0.57 \mu \mathrm{M}$ lipid membrane-forming solution. $\mathrm{AmB}(0.70 \mu \mathrm{M})$ was dissolved to a concentration of approximately $6 \cdot 10^{-4} \mathrm{M}$ in a $3: 1(\mathrm{v} / \mathrm{v})$ mixture of dimethylformamide and $1 \mathrm{M} \mathrm{HCl}$ (aq). A subphase buffer composed of $10 \mathrm{mM}$ Tris-HCl buffer, $\mathrm{pH}$ 7.4, was prepared for the Langmuir experiment. High purity water obtained from a Milli-Q plus water purification system $(18.2 \mathrm{M} \Omega / \mathrm{cm}$, Millipore, USA) was used in all experiments.

\subsection{Langmuir technique}

A Langmuir trough (KSV-Minitrough, Finland) was used to obtain the surface pressure-area per molecule curves of the monolayer at the air-water interface. A Wilhelmy-type tensiometer was used as the pressure sensor. The accuracy of the sensor was $0.1 \mu \mathrm{N} / \mathrm{m}$. A monolayer at the airwater interface of the trough subphase could be symmetrically compressed or expanded with two Teflon barriers at a desired rate. For all the experiments, the temperature was maintained at $35 \pm 01{ }^{\circ} \mathrm{C}$ by an external circulator, and the trough was filled with buffer as the subphase.

Before each run, the Teflon trough (trough size $323 \times 75 \times 5 \mathrm{~mm}$ ) was washed with ethanol and rinsed with purified water. The appropriate volume of sample solution was deposited at the air-water interface with a Hamilton microsyringe. Spreading solvent evaporation over $15 \mathrm{~min}$ and then the monolayers were compressed with a barrier speed of $20 \mathrm{~mm} / \mathrm{min}$. The surface pressure was recorded during the interface compression process. Repeated experiments were performed independently to confirm the reproducibility of the isotherm measurements. 

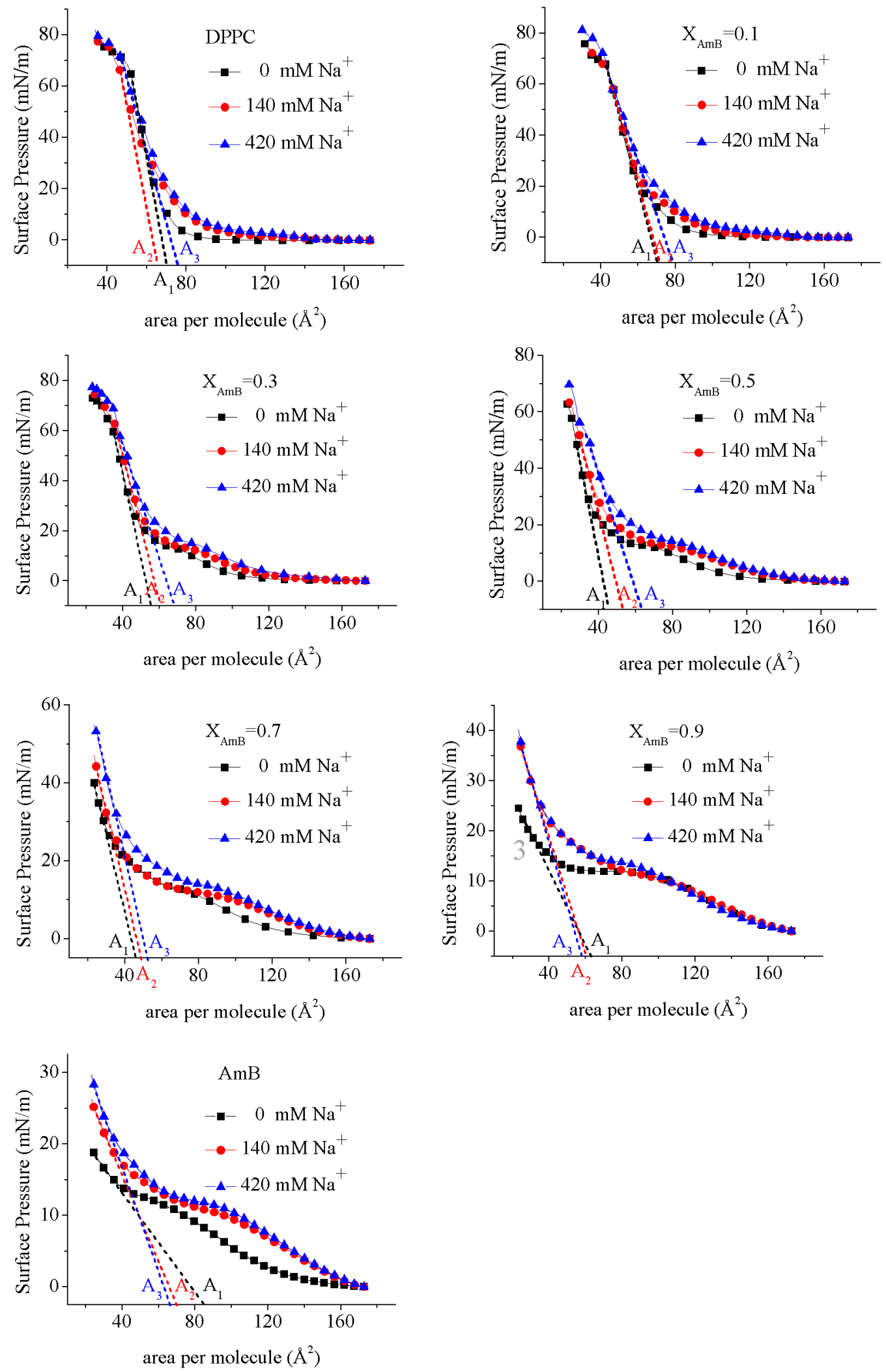

Fig. 1. Surface pressure-area per molecule curves of mixed monolayers $\left(A_{1}, A_{2}, A_{3}\right.$ is the limiting molecular area of the mixed monolayer in $0 \mathrm{mM}, 140 \mathrm{mM}, 420 \mathrm{mM} \mathrm{Na}^{+}$, respectively). 

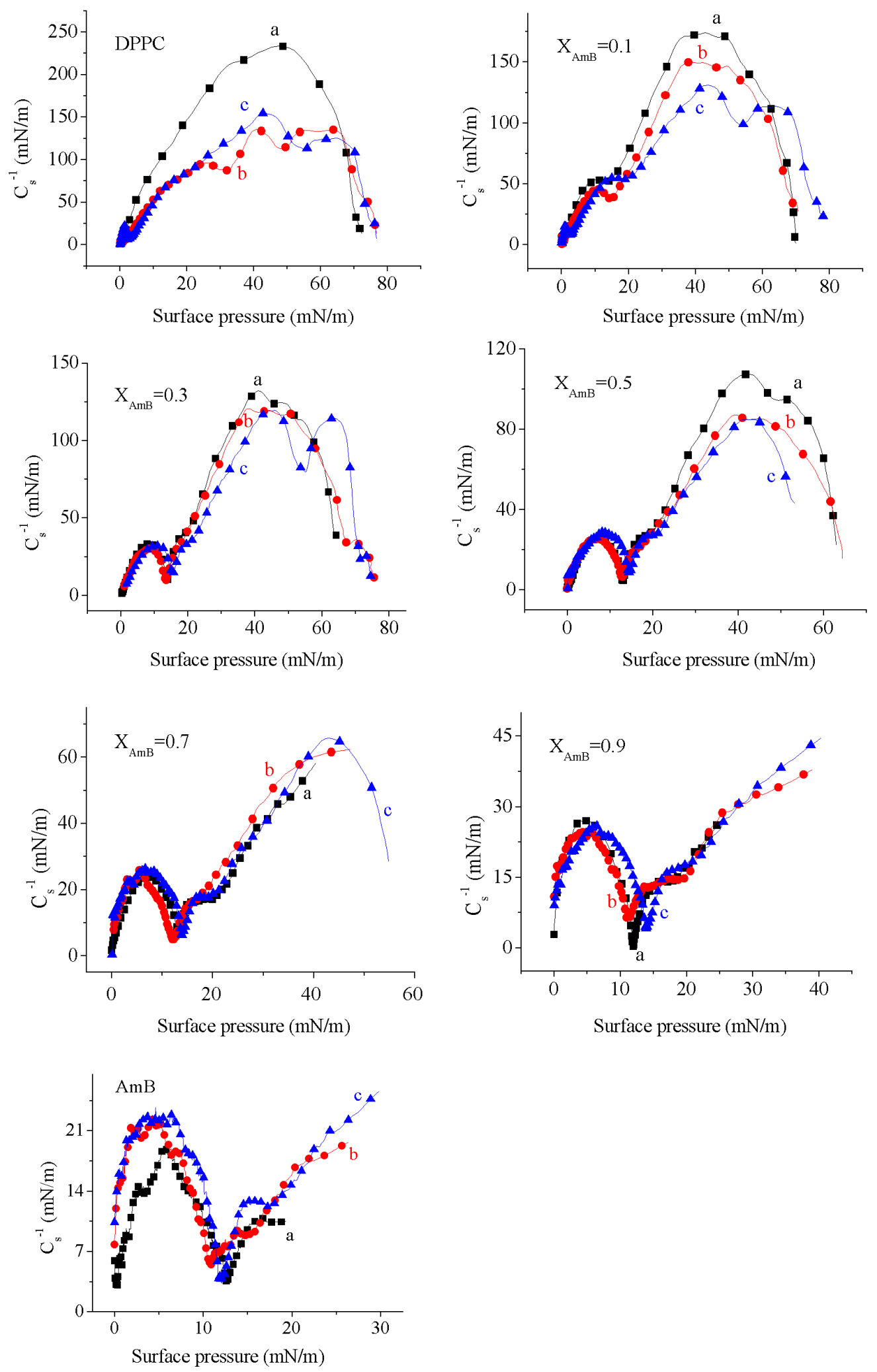

Fig. 2. Compression modulus $C_{s}^{-1}$ of mixed monolayers in $0 \mathrm{mM} \mathrm{Na}^{+}(\mathrm{a}), 140 \mu \mathrm{M} \mathrm{Na}(\mathrm{b}), 420 \mu \mathrm{M}$ $\mathrm{Na}^{+}(\mathrm{c})$. 
Table. Limiting molecular area of the mixed monolayer

\begin{tabular}{|c|c|c|c|c|c|c|c||}
\hline $\begin{array}{c}\text { Limiting molecular } \\
\text { area }\left(\AA^{2}\right)\end{array}$ & $\mathrm{DPPC}$ & $X_{\mathrm{AmB}}=0.1$ & $X_{\mathrm{AmB}}=0.3$ & $X_{\mathrm{AmB}}=0.5$ & $X_{\mathrm{AmB}}=0.7$ & $X_{\mathrm{AmB}}=0.9$ & $\mathrm{AmB}$ \\
\hline$A_{1}$ & 71.3 & 71.6 & 55.7 & 46.2 & 46.3 & 63.8 & 85.9 \\
$A_{2}$ & 65.2 & 72.3 & 60.9 & 54.0 & 49.2 & 60.7 & 71.1 \\
$A_{3}$ & 76.9 & 79.9 & 68.8 & 64.1 & 52.3 & 58.1 & 67.2 \\
\hline
\end{tabular}

\subsection{Thermodynamic parameters of mono- layer}

Compression modulus $C_{s}^{-1}$ can be calculated according to the surface pressure-area per molecule curve by the formula [9-11]:

$$
C_{s}^{-1}=-\frac{A d \pi}{d A}
$$

where $A$ is the area per molecule at the indicated surface pressure $\pi$. The minimum of $C_{s}^{-1}$ suggests the phase transition of monolayer.

Excess Gibbs free energy of mixing $\Delta G^{e x c}$ can suggest the information on the intermolecular interaction of monolayer. It was calculated for binary Langmuir monolayers at a given $\pi$ value according to its definition $[12,13]$ :

$$
\Delta G^{e x c}=N \int_{0}^{\pi} A^{e x c} d \pi,
$$

where $N$ is Avogadro's number.

$A^{\text {exc }}$ is the excess area defined as follows $[14,15]$ :

$$
A^{\text {exc }}=A_{12}-A_{1} X_{1}-A_{2} X_{2},
$$

where $A_{12}$ is the mean molecular area at a given $\pi$ value for the binary monolayer, and $A_{1}$ and $A_{2}$ are the molecular areas of components 1 and 2 , respectively, at the same surface pressure. $X_{1}$ and $X_{2}$ are the molar fractions of single components in the mixed monolayer.

$A_{\text {exc }}$ can be calculated to determine whether two components are immiscible or ideally miscible. A negative value of $\Delta G^{\text {exc }}$ indicates that the intermolecular interaction exhibits attraction [14].

\section{Results and discussion}

\subsection{Phase transition of self-assembled monolayers}

In the process of self-assembly of pure DPPC molecules at the air-water interface, as the concentration of $\mathrm{Na}^{+}$increases, the extent of expansion for $\pi A$ curves at the liquid expansion phase is gradually enhanced. When $X_{A m B}=0.1,0.3,0.7$, the extent of expansion has a similar change to that of pure DPPC monolayer with the increasing of $\mathrm{Na}^{+}$ions' concentration. However, the difference is the extent of expansion for curves at the liquid condensed phase is also gradually enhanced in the creasing of $\mathrm{Na}^{+}$ions' concentration after additon of AmB.

The limit molecular area was calculated from the data points on the surface pressure-area per molecular curve, and the results are shown by dotted lines in the Fig. 1. When the $\mathrm{Na}^{+}$ions' concentration was $0 \mu \mathrm{M}, 140 \mu \mathrm{M}$, and $420 \mu \mathrm{M}$, the limiting molecular area of the monolayer was $A_{1}$, $A_{2}$, and $A_{2}$, respectively (Table).

For a pure DPPC monolayer curve, as the concentration of $\mathrm{Na}^{+}$ions increases, the limiting molecular area decreases firstly and then increases, and $A_{2}<A_{1}<A_{3}$. When $X_{A m B}$, the limiting molecular area also gradually increases with the increase of sodium ions $\left(A_{1}<A_{2}<A_{1}\right)$. However, when, the area of the limiting molecule gradually decreases with the increase of the sodium ion concentration $\left(A_{3}<A_{2}<A_{1}\right)$, which is similar to that for pure AmB monolayer. The difference is that the change is more obvious.

The minimum value of $C_{s}^{-1}$ indicates the phase transition point of the monolayer film. From the Fig. 2, we can see that for pure DPPC, when the concentration of $\mathrm{Na}^{+}$ is $420 \mathrm{mM}$, the curve has a phase transition point at over the surface pressure of $56 \mathrm{mN} / \mathrm{m}$. When the concentration of $\mathrm{Na}^{+}$is reduced to $140 \mu \mathrm{M}$, two phase transition points appears at $32 \mathrm{mN} / \mathrm{m}$ and $48 \mathrm{mN} / \mathrm{m}$. This may be due to the fact that the orientation of the DPPC molecules at the interface are affected by the $\mathrm{Na}^{+}$ions. At a certain range of surface pressure, the DPPC molecules may be rearranged. This phenomenon can not be observed without sodium ions.

After addition of AmB, when $X_{A m B}$, the two phase transition points of mixed 

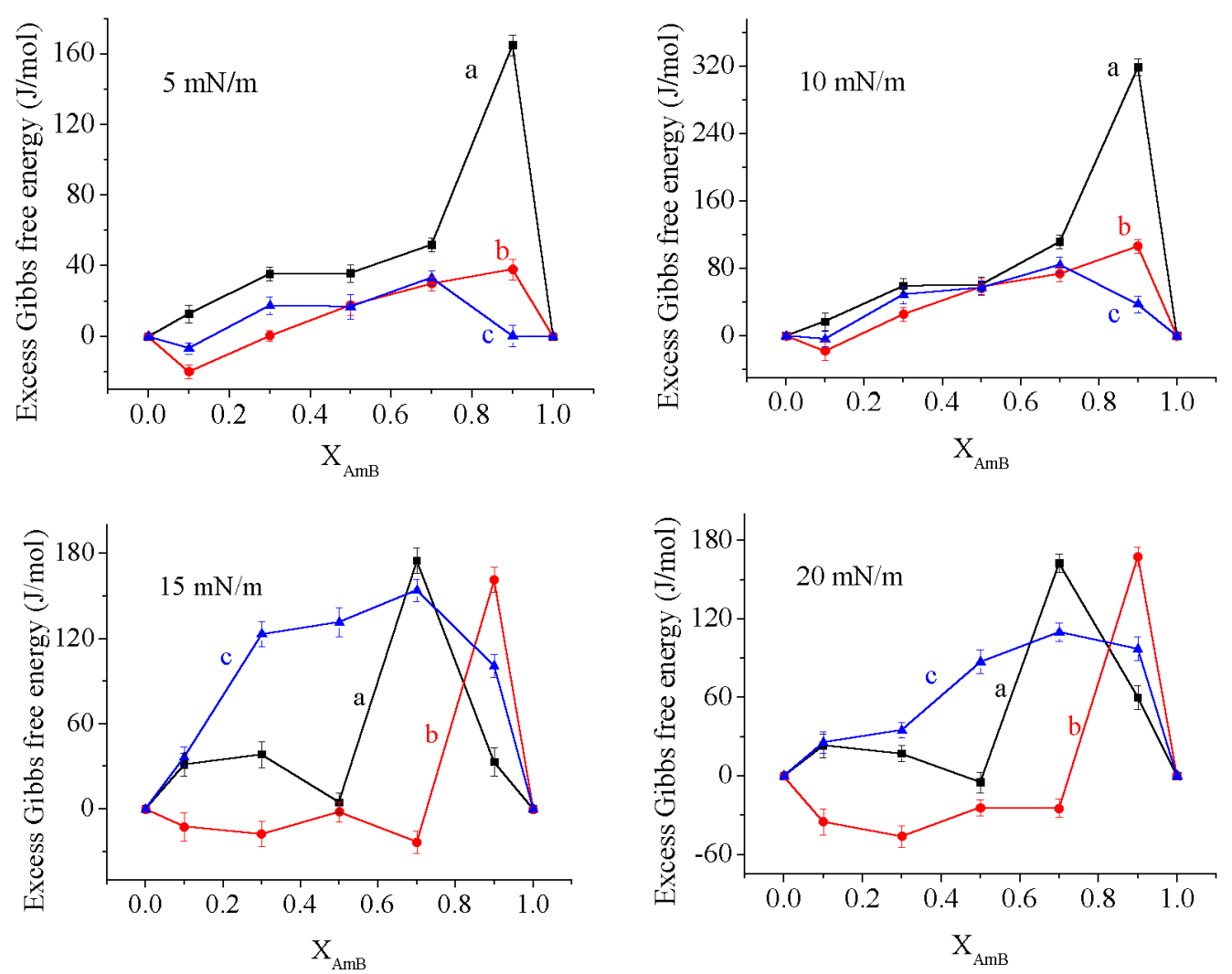

Fig. 3. Excess Gibbs free energy of mixed monolayers in $0 \mathrm{mM} \mathrm{Na}^{+}(\mathrm{a}), 140 \mathrm{mM} \mathrm{Na}{ }^{+}(\mathrm{b}), 420 \mathrm{mM} \mathrm{Na}^{+}$(c)

monolayer at the surface pressure of 32 and $48 \mathrm{mN} / \mathrm{m}$ have disappeared in $140 \mathrm{mM} \mathrm{Na}^{+}$. But when the sodium ions' concentration was $420 \mu \mathrm{M}$, the phase transition point at $56 \mathrm{mN} / \mathrm{m}$ is still present. As the proportion of AmB continues to increase, the phase transition point disappears.

It is shown that the concentration of sodium ion has a great influence on the phase transition of DPPC monolayer. In addition, AmB changes the phase transition of DPPC at high surface pressures in the presence of sodium ions.

\subsection{Interaction between the super-} molecules

When $X_{\mathrm{AmB}}$, at the surface pressure of 5 or $10 \mathrm{mN} / \mathrm{m}$, the excess gibbs free energy is positive in the absence of $\mathrm{Na}^{+}$ions (Fig. 3). This suggests that there is repulsion between the molecules. However, in the presence of $\mathrm{Na}^{+}$ions, the excess gibbs free energy is negative, which shows that the interaction between molecules is gravity. In addition, the larger the sodium concentration, the excess gibbs free energy of the monolayer is smaller, which means the interaction force between the molecules is weaker. Differently, at the surface pressure of 15 or $20 \mathrm{mN} / \mathrm{m}$, the excess gibbs free energy becomes positive when the concentration sodium ions goes up to $420 \mathrm{mM}$, and the intermolecular interactions become repulsive.

When $X_{\mathrm{AmB}}$, at the surface pressure of 5 or $10 \mathrm{mN} / \mathrm{m}$, the excess gibbs free energy is positive and the intermolecular interactions is repulsion. Differently, at the surface pressure of 15 or $20 \mathrm{mN} / \mathrm{m}$, the value of excess gibbs free energy becomes negative, and the interaction between molecules is shown as gravitation when the concentration of sodium ions is $140 \mathrm{mM}$. This indicates that the sodium ions in appropriate concentration could promote the tight arrangement of molecules.

When $X_{A m B}$ at $5 \mathrm{mN} / \mathrm{m}$ or $10 \mathrm{mN} / \mathrm{m}$, the value of the excess gibbs free energy is positive. Moreover, with the increasing of sodium ion concentration, the value of excessive gibbs free energy decreases gradually. It is shown that the interaction force between molecules on the monolayer is repulsion, and the repulsion decreases gradually as the increasing of sodium ion concentration. When the surface pressure goes up 
to 15 and $20 \mathrm{mN} / \mathrm{m}$, the value of the excess gibbs free energy is positive, which is similar to that at low surface pressure. However, when in the presence of $140 \mathrm{mM} \mathrm{Na}^{+}$ ions, the excess gibbs free energy is maximal, and the repulsion between molecules is stronger than that in other conditions of this work. The interaction between molecules is closely related to the distribution and arrangement of molecules on the monolayer.

\section{Conclusions}

From the above, the effect of sodium ion on the liquid expansion phase, the limiting molecular area, phase transition and intermolecular forces of mixed monolayer films depends on the composition of amphotericin $\mathrm{B}$ in the membrane. The influence of sodium ions on the limiting molecular area is relative to the proportion of amphotericin $\mathrm{B}$ in mixed membrane. The smaller the area of the limiting molecule, the smaller the distance between the molecules on the mixed monolayer, and the closer the formation of the monolayer. The effect of sodium ions on the phase change of mixed monolayer is also related to the concentration of amphotericin $\mathrm{B}$. With the increase of concentration of amphotericin B at high surface pressure, sodium ions make the phase transition points of mixed monolayer gradually disappear, which shows that sodium ions mainly interact with amphotericin $\mathrm{B}$.

There is a correlation between the intermolecular forces and the monolayer membrane structure. The $\mathrm{Na}^{+}$ions may affect the molecular orientation of amphotericin $B$, and it may mainly depend on the concentration of sodium ions. The low concentration of sodium ions could increase the attraction between molecules but the high concentration of sodium ions increases the mutual repulsive force between molecules.

Acknowledgements

The study was supported by the National

Natural Science Foundation of China (Grant: 51407184), the Doctor's Special Foundation of Xijing University (Grant: XJ17T02).

\section{References}

1. Dynarowicz-Latka P, Minoes Jr. J, Conde O, et al., Appl. Surf. Scien., 246, 334, 2005.

2. Ganrrignes J C, Ricco-Lattes I, Perez E, et al. Langmuir, 14 , 5968, 1998.

3. Ermishkin L N, Kasumov K M, Potzeluyev, Nature, 262, 698, 1976.

4. Andreoli T E. Annals New York Acad Scien, 235, 448, 1974.

5. Katsu T, Okada S, Imamura T, et al., Anal. Scien, 24, 1551, 2008 .

6. Gagos M, Arczewska M., $J$ Phys Chem B, 115, 3185, 2011.

7. Becucci L, Innocenti M, Bellandi S, et al., Electrochim Acta, 112, 719 , 2013.

8. Turcu R, Patterson M J, Omar S., Pediatric Nephrology, 24, 497, 2009.

9. Zakanda F N, Laurent P, Paquot M, et al. Thin Solid Films, 520, 344, 2011.

10. Wang J, Sun R G, Hao C C., Scien China Chem, 57, 1538, 2014.

11. Nakahara H, Nakamura S, Okahashi Y, et al., Colloids Surfaces B- Biointerfaces, 102, 472, 2013.

12. Gzyl-Malcher B, Handzlik J, Klekowska E. Bioelectrochem, 87, 96, 2012.

13. Wang J, Shi R X, Sun R G, et al. Chin Phys B, 25, $090505,2016$.

14. Panda A K, Wojciechowski P, Nag S, et al. J Display Techn, 30, 1255, 2009.

15. Wang J, Sun R G, Hao C C, et al., Chem Research Chine Univ, 33, $447,2017$. 